\title{
Study on the Improvement of Public Participation for Public Works in China*
}

\author{
Cao Yiyue \\ International Business School, \\ Yunnan University of Finance and Economics \\ Kunming, China \\ 1039851090@qq.com
}

\author{
Jiang Qifa* \\ International Business School, \\ Yunnan University of Finance and Economics \\ Kunming, China \\ fagenjiang3@163.com
}

\begin{abstract}
With the rapid development of Chinese economy and the improvement of people's consciousness of democracy, greater participant demands are being placed on public works related to individual interests. In order to deal with the challenges of strengthening the investment performance and quality of public works, citizens should be encouraged to actively participate in the designing, implementation and decision-making stage. Suitable ways and regulations for public participation should be enacted by governments to improve the project performance and satisfaction of citizens, and finally to make a better achievement for public works.
\end{abstract}

Keywords-Public Participation, Public Works, Improvement

\section{INTRODUCTION}

As a developing country, especially in the stage of economic take-off, investment generally constitutes of great portion of GDP in China. For example, the investment rate was $46.7 \%$ against GDP in 2014 [1], therefore sometimes China is called as an investment-oriented economy.

In this background, Chinese public works develop very fast with increasingly GDP in recent years. As shown in Table 1 and Figure 1, Chinese whole social fixed assets investment (WSFAI) is 25.17 trillion CNY in 2011 and up to 56.20 trillion $\mathrm{CNY}$ in 2015. We can see from the figure that the whole society asset investment is increasing year by year. In this situation, there are many construction projects in China every year and how to improve public satisfaction of the public construction projects becomes a key issue.

TABLE I. THE DATA ON THE WHOLE SOCIAL FIXED ASSETS INVESTMENT

\begin{tabular}{|c|c|c|c|c|c|c|}
\hline Year & $\mathbf{2 0 1 0}$ & $\mathbf{2 0 1 1}$ & $\mathbf{2 0 1 2}$ & $\mathbf{2 0 1 3}$ & $\mathbf{2 0 1 4}$ & $\mathbf{2 0 1 5}$ \\
\hline $\begin{array}{c}\text { WSFAI } \\
\text { (billion CNY) }\end{array}$ & 25168.38 & 31148.51 & 37469.47 & 44629.41 & 51202.07 & 56200.00 \\
\hline
\end{tabular}

a. Source: Adopted from the Website of the National Bureau of Statistics of China

* Corresponding author

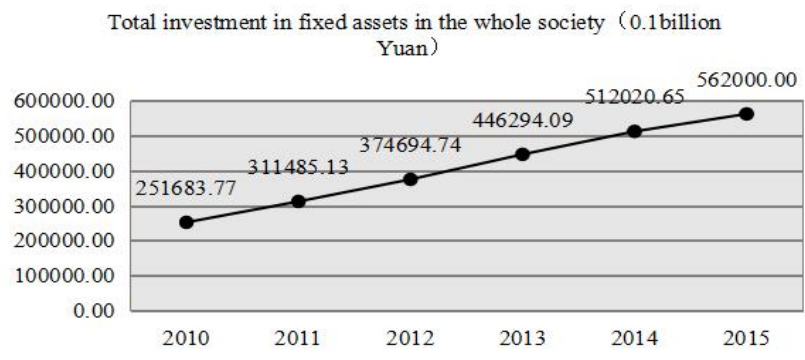

Fig. 1. The Increase of the Whole Social Fixed Assets Investment in China

During the construction of public works the project fund is generally made up of the central government, local governments and private capital, which frequently the government investment accounts for the largest portion [2]. In the stage of economic transition from a central-planned economy to a socialist market economy, the public works is not yet perfect in China. There exist many problems such as low level of decision-making, low investment benefit, loss serious waste of investment, low level repeated construction [3], etc. On the other hand, government investment often results in corruption, bureaucracy, and finally public dissatisfaction [4].

The construction of public works project is actually a process of interests balancing and distribution among different stakeholders. Yet because of insufficient public participation that only a handful of officials and experts can involve in the process of public works' decision making [5]. Other serious problems are then accumulated [6], such as environmental pollution, inequity and injustice, rent-seeking, and vegetation deterioration, etc.

To deal with the above problems, it is a good solution to introduce public participation during the construction of public works. Actually, sufficient public participation and assurance mechanism can overcome many problems such as resolving many interest conflicts and disputes, realizing civil rights, preventing the abuse of public power, harmonizing the society, and making the public works' decision-making more transparent, scientific and democratic [7]. Public participation is the cornerstone of solving the problems during the construction of public works and it is critical to improve it to make a better performance for the public projects. 


\section{THE SIGNIFICANCE AND NECESSITY OF PUBLIC PARTICIPATION IN THE CONSTRUCTION OF PUBLIC WORKS}

\section{A. The significance of public participation in public project}

Actually some form of public participation has always been critical to Chinese system of governance and decision making, yet the analysis and study of effective public participation are still necessary to be deep developed [8]. Why do we emphasize the importance of effective and efficient public participation during public works? The reasons are based on the following factors:

Citizen participation makes the public construction project decision-making scientific and reasonable, and then expand capacity, reduce costs [9]. For public decision, because of lack of information, it is difficult to make a scientific and rational decision-making. Yet the public has abundant information, and can make decision effectively based on individual knowledge. Thus public participation processes seek to expand governmental and private sector capacity, coupled with a reduction in overall costs of implementation and public relations.

To governments, one of important aims of public participation is to legitimize policy and management decisions [10], and reach substantively better decisions. After interactive learning, stakeholders involvement, the participatory process can establish mutual trust and strategic alliance between governments and citizens, improve the performance of public project, and finally achieve a better satisfactory result.

In addition, citizen participation is the guarantee of the smooth implementation of public works project construction, and can foster better democracy [11].

\section{B. The necessity of public participation in public project}

In recent years, with the development of Chinese economy, people's living standard is fast increasing and caring more and more about their own interests. In the context of awareness of citizen's right, however, based on the following facts, it is a great need to adopt more effective public participation:

Firstly, though there exists some public participation channels in China, such as government telephone hotline, hearing, citizen suggestion box, yet the effectiveness of these methods is very poor.

Secondly, the breadth and depth of public participation is insufficient, so does the degree of information [12]. Although Chinese public participation is strengthening gradually, but the vast majority of people cannot effectively participate in the project construction stages due to factors such as living environment, cultural level, social status and so on. What's more, because public participation is a time-waste process and might be high costly, not all public institutions are not prepared to involve in the process.

Thirdly, the organizers and participants are short of continuity and interactive. The process of participation does not form a continuous process, e.g. a cycle of participation feedback - re-engagement [13]. So many governments are just going to turn a deaf ear to the public advice, and not give any feedback to the public opinions.

Other problems in public participation of public project include passive and single participatory ways, small scale of the participatory bodies, not prompt information revelation, lack of public participatory channels, and imperfect safeguard mechanism of participatory rights.

Therefore, Chinese governments should strengthen and protect the public to participate more effectively in public works.

\section{THE ANALYSIS OF CHANNELS OF PUBLIC PARTICIPATION IN CHINA}

\section{A. The definition of public works and public participation}

Public works is also called a non-competitive projects, which refer to the projects mainly invested by central or local governments, and aim to provide public goods or services. Differing from common projects, public works generally own characteristics of significant externalities, and involve the public interest. Decision makers during the investment do not just consider financial profits but comprehensive benefits including macroeconomic benefit, environmental benefit and social benefit.

What is public participation? The term has numerous different meanings and definitions, always viewed differently depending on its contexts and purposes. Not just relating to participation at public hearing in the past, at present this term refers to a diversity of procedures for facilitating members of the public to be effective participants in deliberations in decision-making processes [14].

In this study, public participation can be defined as: "a range of activities, or processes, by which all directly or indirectly affected and interested parties, including individuals and organizations, through formal or informal legal way, are engaged in the decision-making process to prevent or resolve a conflict and to achieve consensus and its objective through a mutual two-way communication before decisions are made" [15]. Involved in their own interests, and published their own opinions and views, the stakeholders attempt to affect the activities of the government decision-making.

\section{B. The analysis of channels of public participation}

B. H. Westley and M.S. Maclean, who proposed a communication mode in "A Conceptual Model for Communication Research", [16] summarized the general pattern of public participation as shown in Figure 2:

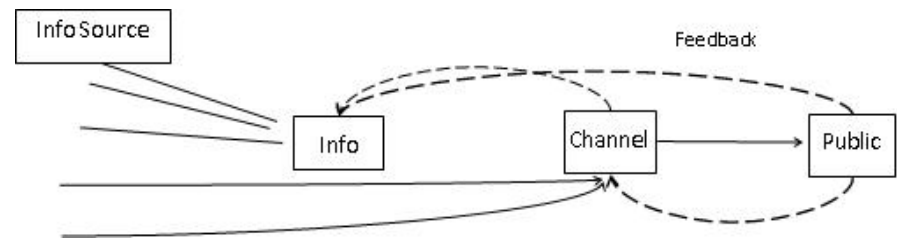

Fig. 2. The Model of Information Transmission.

In China, main ways of public participation include information communication, consultation, participation, 
collaboration, and authorization decisions. Different people have different living environment, cultural level, social status, working environment, and their way of thinking, behavior, legal consciousness and ability. So the different participation methods are suitable for different people.

For example, difference ages can make a person act and think in different maturity; Different social classes have different power and information source; Different education background will make people have different way of thinking, behavior and ability. Therefore, based on three types of indicators, e.g. different age, social status, education background, we can classify the suitable ways of participation for different people in China. The final result is shown in the below Table 2:

TABLE II. SUITABle WAYS OF PUBliC PARTICIPATION FOR DIFFERENT PEOPLE IN CHINA

\begin{tabular}{|c|c|c|}
\hline Type of Indicators & Classification & The way of participation \\
\hline \multirow{4}{*}{ Age } & -18 & $\begin{array}{l}\text { Exchanges } \\
\text { consultation } \\
\text { information }\end{array}$ \\
\hline & $18-30$ & \multirow{3}{*}{$\begin{array}{l}\text { Participation, } \\
\text { collaboration and } \\
\text { authorization decisions }\end{array}$} \\
\hline & $31-50$ & \\
\hline & $50-$ & \\
\hline \multirow{3}{*}{ Social status } & The upper society & \multirow{2}{*}{$\begin{array}{l}\text { Participation, } \\
\text { collaboration and } \\
\text { authorization decisions }\end{array}$} \\
\hline & Middle-class & \\
\hline & The grassroots & \multirow{2}{*}{$\begin{array}{l}\text { Exchanges } \\
\text { consultation } \\
\text { information }\end{array}$} \\
\hline \multirow{3}{*}{$\begin{array}{l}\text { Education } \\
\text { background }\end{array}$} & -Primary school & \\
\hline & $\begin{array}{l}\text { Junior school and } \\
\text { high school }\end{array}$ & $\begin{array}{l}\text { Exchange } \\
\text { information, } \\
\text { consultation } \\
\text { participation }\end{array}$ \\
\hline & College- & $\begin{array}{l}\text { Participation, } \\
\text { collaboration and } \\
\text { authorization decisions }\end{array}$ \\
\hline
\end{tabular}

Among the ways of participation, all are inclusive a package of many methods, for example, information communication includes packets, booklets, leaflets, fact sheet, website, exhibition, television and radio, research, questionnaire survey, focus group, etc. The below Table 3 shows the package:

TABLE III. THE PACKAGE OF METHODS FOR PUBLIC PARTICIPATORY WAYS

\begin{tabular}{|l|l|}
\hline \multicolumn{1}{|c|}{ The way of participation } & \multicolumn{1}{|c|}{ The package } \\
\hline Information communication & $\begin{array}{l}\text { Packets, booklets, leaflets, fact sheet, } \\
\text { website, exhibition, television and } \\
\text { radio, research, questionnaire survey, } \\
\text { focus group, etc. }\end{array}$ \\
\hline Information consultation & $\begin{array}{l}\text { Research, questionnaire, survey, public } \\
\text { meetings, focus group, residents' panel, } \\
\text { etc. }\end{array}$ \\
\hline Participation & $\begin{array}{l}\text { Interactive working group, stakeholders } \\
\text { dialogue, citizen forum and debate, etc. }\end{array}$ \\
\hline Collaboration & $\begin{array}{l}\text { Advisory panel, local strategic partners } \\
\text { and local management organization, etc. }\end{array}$ \\
\hline Authorization decisions & $\begin{array}{l}\text { Local mass organizations, regional } \\
\text { panel, community partners, etc. }\end{array}$ \\
\hline
\end{tabular}

After discussing the suitable participatory ways and package for different people, governments should formulate corresponding desired public participatory policy for different crowd, to make every citizen have opportunities to participate effectively in the construction of public works

\section{RECOMMENDATIONS OF IMPROVING PUBLIC PARTICIPATION FOR PUBLIC WORKS}

\section{A. Perfecting the legal system of public participation}

1) Strengthen the construction of the institutionalization of public participation: In order to make the public to participate actively in public works, governments should establish and perfect the legal system, protect the rights of public participation in the project construction, clear the corresponding position and functions of the government and the public in public works projects [17].

2) Protect the public rights to know and participate: As a member of the People's Republic of China, every citizen has rights to understand the relevant information about the public works, and publish their own views and suggestions on the construction.

Rights to know refers to knowledge, freedom and rights of access to information, including obtaining relevant knowledge officially or unofficially. When we guarantee citizens' right to know, then we can make the citizen understand the project deeper and involve it actively. Therefore the government should publish the relevant information regularly and inform the citizen in time to ensure the transparency of information. At the same time, it is important to guarantee the citizen's access to information smooth and free.

Rights to participate refer to the citizens' rights to participate in the administration of public works and make decision in accordance with the provisions of the law. To ensure the participation of citizens, the government should give citizens full freedom to participate in the process of planning, decision-making and construction of public works, etc. under the circumstance of maintaining the original law system. Governments' responsibility is to formulate corresponding laws and regulations, clear the rules and defend the freedom of citizen participation.

\section{B. Strengthen the consciousness of public participation}

1) Improve citizen's self-awareness: Public works can not be treated as normal but related to social welfare and people's well-being. Yet public participation can not just be regarded as a kind of obligation but also as a right to sageguard individual interest.

2) Encourage citizens to popularize the related knowledge: In order to enable citizens participate in public works more efficiently, it is necessary to encourage the public to learn about professional knowledge, such as relevant laws and regulations, construction procedures, methods, etc. What's more, we should learn more about the variety of modern communication tools to improve the efficiency and effectiveness of participation.

3) Speed up the construction of civic culture: In China, due to the influence of traditional culture, the vast majority of citizens generally lacks independent thinking and will just 
follow the rules of governments. In this condition, people will view that the construction of public works is none business of individual but just the responsibility of the government, which thus results in a passive participation. In order to get rid of this phenomenon, the government should cultivate citizens' subject consciousness, set up citizen's democratic value, speed up the cultivating of civic culture, encourage citizens to participate in the public works, and live up to their rights and obligations.

4) Create a good political and cultural atmosphere: To serve the people better, governments bear the responsibility to provide the public with a good political culture atmosphere. The government should promote scientific and democratic spirit, respect the wishes of the public, cultivate the public consciousness of rights and responsibility, involve citizens into the affairs of project construction actively.

Actually, participatory processes fundamentally involve delegation or sharing of decision-making power, what means that the process should develop step by step. Around the power sharing relationship some frameworks are created to illustrate this process. The most widely cited model, is Arnstein's (1969) 'ladder of citizen participation', as shown in Figure 3, which illustrates the basic concept that the public may receive anything from no decision power or influence to essentially complete control and authority [18]. From the model we can learn that it will take a long time to foster the participatory culture and develop at last to a high level of public participation.

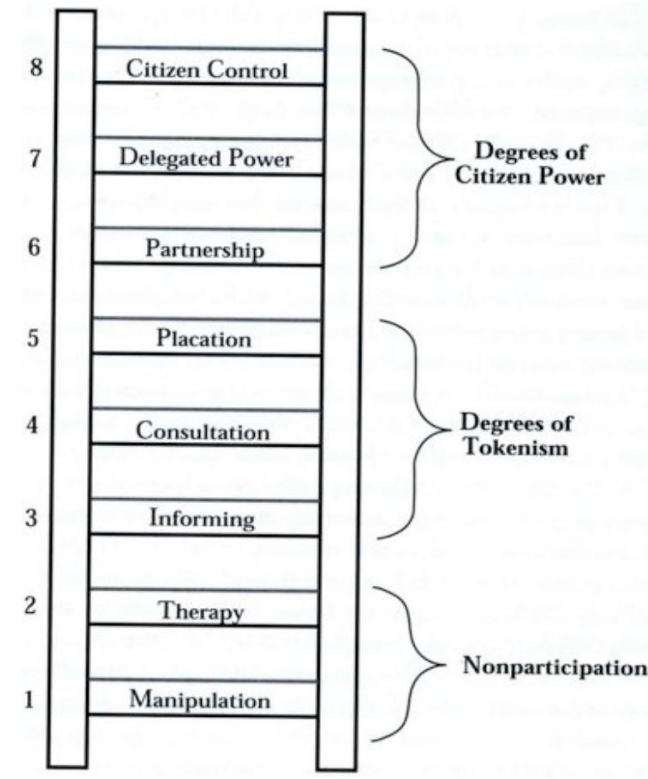

Fig. 3. The ladder of citizen participation.

b. Source: Arnstein, 1969

\section{Broadening the channels of public participation}

In order to make the citizens to participate in the public works projects actively, it is better to make the citizens to participate in the public works actively, and at the same time to improve the effectiveness of public participation, in addition to guarantee information publicity, participate in more channels and so on. Governments also should learn lessons from foreign experience, combine the principal of participation with Chinese environment, and try to adopt new public participatory methods.

For example, many new methods can introduce into public participation, such as: (1) citizens juries; (2) citizen panels; (3) focus groups; (4) advisory panels; (5) local strategic partners; (6) neighborhood councils; (7) public survey; (8) public debate; (9) E - town meeting; (10) government exhibitions, etc.

And it also should introduce the third party participation, strengthen evaluation and efficiency of the activity, improve the citizens' legal consciousness and other methods to promote the quality of public participation.

\section{CONCLUSIONS}

During the construction of public works, public participation is very important. This is the way to guarantee that public works can be made decision scientifically and reasonably, implemented smoothly. But at present Chinese public participation in public works is still in its infancy, public participation method is unitary, and also facing the factors' constraints, such as system, law, technology, and the public's awareness of participation and so on. Therefore, through perfecting the legal system, cultivating the consciousness and conducting the assessment of public participation, strengthening the third party participation, etc. we then can improve better measures and ensure that the public will participate in public works more efficiently and effectively.

Only after these countermeasures, the public participation in public works will develop quickly in China.

\section{REFERENCES}

[1] "National bureau of statistics. China statistical yearbook," Beijing: China statistics press, 2014.

[2] James L. Creighton. "The Public Participation Handbook: Making Better Decisions Through Citizen Involvement," San Francisco: Jossey-Bass Publishers, 2005.

[3] T. Huang, L.Y. Shen, and Z.Y. Zhao, "The Analysis of Present Administration for Government Investment Projects in China," Construction Economy, pp. 16-20, January 2005.

[4] Y. Wang and C. Chen, "The Study on the Performance Appraisal System of Government Investment Projects in the City of Baoding," Hebei Enterprises, pp. 57, April 2016.

[5] D.F. Wang, "Study on the Effectiveness of Public Participation of Social Appraisal for Public Works," Learning Theory, 2013, pp. 6-6.

[6] Z.G. Liu, "Thoughts on the Problems and Countermeasures of Administration for Government Investment Projects," Special Zone Economy, pp. 210-213, August 2007.

[7] Y. Moseti "Public Participation for Sustainable Development in Local Cities," Kenya: the 46th ISOCARP Congress, 2010.

[8] R.J. Mason, "Collaborative land use management: The quiter revolution in place-based planning," New York: Rowman \& Littlefield Publishers, INc., 2008.

[9] R.A. Irvin and J. Stansbury, "Citizen participation in decision making: Is it worth the effort?" Public Administration Review, vol. 64, 2004, pp. 55-65.

[10] K.E. Halvorsen, "Assessing the Effects of Public Participation," Public Administration Review, vol. 63, 2003, pp. 535-543.

[11] K.E. Halvorsen, "Assessing the Effects of Public Participation," Public Administration Review, vol. 63, 2003, pp. 535-543. 
[12] J.Q. Xiao, "Build a Mechanism of Information Opening for Government Investment Projects," Study on the culture of clean government, 2011, pp. 15-20.

[13] S.X. Duan, "The Thoughts on the Mechanism of Public Participation for Chinese Megaprojects," Ningxia Social Science, 2012, pp. 67.

[14] T. Webler and S. Tuler, "Four perspectives on public participation process in environmental assessment and decision making: Combined results from 10 case studies," Policy Stud. J., vol. 34, 2006, pp. 699-722.

[15] Chutarat Chompunth and Suphattharachai Chomphan, "Evaluating Public Participation Process in Development Projects in Thailand: A
Case Study of the Hin Krut Power Plant Project," American Journal of Applied Sciences, vol. 9, 2012, pp. 865-873.

[16] B.H. Westley and M.S. Maclean, "A Conceptual Model for Communication Research," Journalism \& Mass Communication Quarterly, vol. 34, 1957, pp. 31-38.

[17] Y.J. Hua, X. Chen, and J. Zhang, "Analysis on the Indicators of Social Appraisal for Public Works," Journals of Chongqing University, vol. 28, 2005 , pp. 145-145.

[18] Sherry R. Arnstein, “A Ladder of Citizen Participation,” Journal of the American Planning Association, vol. 35, pp. 216-224, July 1969. 